\title{
Port-city relationships in Europe and Asia
}

\author{
César Ducruet*
}

\begin{abstract}
This paper investigates the nature of port-city relationships in two major port regions of the world, Europe and Asia. Although this issue is well analyzed through either isolated case studies or general models, it proposes a complementary approach based on urban and port indicators available for 121 port cities. In terms of demographic size and container traffic, it shows the decline of port-urban dependence, stemming from changes in global transportation and urban development. However, European and Asian port cities are not identically confronted to the same challenges, notably in terms of their hinterlands. A factor analysis highlights a regional differentiation of port-city relationships according to their insertion in both urban and port systems, with a core-periphery dualism in Europe and a port-city hierarchy in Asia. Thus, the distance to inland markets for European ports and the size of coastal markets for Asian ports are the main factors to explain the nature of port-city relationships in the two areas. It helps to evaluate which European and Asian port cities are comparable beyond their cargo volumes, by putting together micro (local environments) and macro (regional patterns) factors.
\end{abstract}

Keywords: Asia; Europe; Factor analysis; Port city

\section{Introduction}

Port cities are strategic nodes for major trading regions such as Europe and Asia, especially in a world where more than $90 \%$ of trade volumes occur by sea (Rodrigue, 2006). However, their roles are different for a number of reasons, such as the history of trade and urban settlements, the

Submission Date: 8/9/2006 Acceptance Date: 11/27/2006

"Korea Research Institute for Human Settlements (KRIHS)Northeast Asian Regional Development Center 1591-6 Gwanyang-dong, Dongan-gu, Anyang-si, Gyeonggi-do 431-712 Republic of Korea. Tel. +82 (0)31-380-0183 / Fax+82 (0)31-380-0482 / Email: dcducruet@aol.com 
geographical layout, and the current level of regional integration. In Europe, the importance of inland cities is reflected in the "central place" paradigm, and port cities have often been disregarded by urban specialists (Bird, 1973). Most European urban comparisons verify the lower economic importance of port cities (Brunet, 1989; Rozenblat and Cicille, 2002; IRSIT, 2004). In Asia, since the colonial period and following the coastal industrialization in Japan, the Dragons and Tigers and China, port cities are vital propellers of development, to the expense of inland cities. They have become the new cores of their national economies (Gipouloux, 2001).

Although the different roles have been studied from historical and geographical perspective in Europe (Hoyle and Pinder, 1992; Lawton and Lee, 2002) and Asia (Basu, 1985; Broeze, 1989, 1997; Lee, 2005) through several case studies, few scholars have attempted a direct comparison. According to some of them, Western models of port-city growth are not applicable to Asian countries (Arasaratnam, 1992), but for others, it is fruitful to analyze how port regions adapt differently to a same global phenomena, such as waterfront redevelopment (Hoyle, 2000a). However, the lack of comparable data has limited the quantitative analysis of port-city relationships (Wang and Olivier, 2003), hampering direct international comparisons (Ducruet, 2004). This paper is an attempt to overcome such limitations, arguing that using basic urban and port indicators is sufficient to verify general models. Based on previous works on Asian and European port cities (Ducruet, 2003; Ducruet and Jeong, 2005), it verifies the combinations of port and urban functions through a principal component analysis. This methodology is a means to highlight several key issues such as the importance of ports in local economies, the importance of hinterlands, and the degree of intermodality. It is believed that those issues are differently represented in the two areas.

The first section reviews the major differences between Europe and Asia in terms of hinterland expansion and port competition. Next, the second section proposes an overview of the port-urban dependence in the two areas, based on the evolution of container traffic and urban population from 1970 to 2005 . The third section introduces the ten indicators, and proposes a geographical interpretation and typology of port cities from the results of the principal component analysis. Finally, implications are given about the lessons learned in terms of regional integration in the two regions.

\section{European and Asian port-city systems}

\subsection{The role of the hinterland}

In Europe, main markets and settlements are located in the "heartland" of the continent; then even major ports are in a peripheral situation to serve their customers. Port authorities in Europe are then engaged, since the spread of containerization, in a reflection on the most efficient way to connect a maximum of inland cities through intermodal services (e.g. river barging, sea-rail, roadrail and even air-sea). In this respect, most coastal cities are suffering from this peripheral location, that has direct effects on their economic structure (e.g. specialization in transport activities), as inland cities tend to retain higher-value activities such as banking, finance and other "metropolitan" functions. Thus, European researchers have been focusing on the way to develop alternative 
strategies to shipping, to diversify local economies notably since maritime-related business have suffered from employment decline (e.g. shipbuilding, stevedoring) and are no longer benefiting local economies (Benacchio et al., 2001). An acute debate still lingers on, between partisans of port-related urban development based on logistics, and partisans of taking advantage of coastal locations without depending on uneven port activity (e.g. cultural or commercial citizen-oriented strategy). Moreover, the increasing environmental concern tends to accentuate the port-city separation, as waterfronts are redeveloped for other uses and modern port functions are locating away from inner cities.

In Asia, as settlement patterns are mostly coastal, port cities are the most important markets for ports. The colonial model in South and South East Asia has had the effect to combine urban and port hierarchies along trading regions, through the establishment of depots and entrepots in strategic locations such as Singapore and Hong Kong. In fact, most primate Asian cities are port cities, and still now keep a high share in the volume of goods transported to and from Europe and North America. The rapid development of North-East Asia gave birth to some of the world's most combined models of port-city relationships, such as free trade zones in Taiwan, Korea, China and the enormous reclamations in Japan in the 1970s and 1980s. As a consequence of physical geography (island states) and historical coastal concentration, inland transportation and markets are still underdeveloped. The lack of inland connections between South and East Asia, and between South Korea, Japan, Taiwan, Philippines and the continent, is preventing ports from connecting with other countries' markets. Then in Asia, ports and cities have been developing and improving their functions in a symbiotic way. Intermodal transportation is also a secondary concern, except from some specific cases like air-sea in Hong Kong and Singapore, and sea-river in Shanghai.

As shown in Fig.1, such spatial patterns give transport and urban decision-makers very different stakes to overcome so as to realize their policy, as urban coastal economies are "residual" markets in Europe and "core" markets in Asia (Australia, Africa, South America). Another important difference is coming from the level of regional integration, as European ports compete for a single market whereas Asian ports are still focused on a national economy, but are also developing hub functions for regional competition.

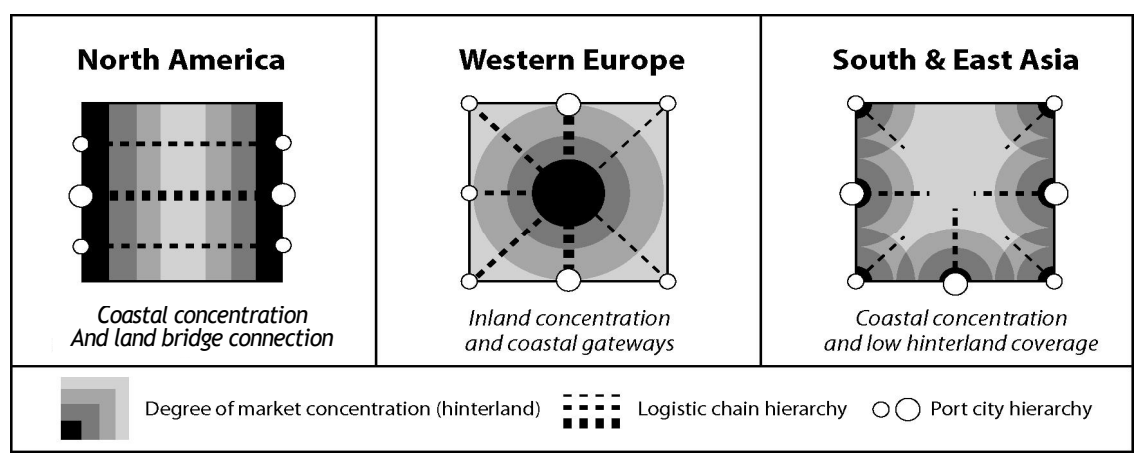

Source: Lee, Song \& Ducruet, 2006

Fig. 1. Models of hinterland organization in the world's main port regions 


\subsection{Integration level and port competition}

Within a single market, ports in the European Union are competing for more and more overlapping hinterlands. It is now famous that Le Havre port authority and dock workers blame Antwerpen (Belgium) players for 'unfair competition', as Antwerp was catching the Paris region market due to Le Havre's incapacity to enlarge its radiance through rail and barge regular services to the East. For example, the whole French production of bottled mineral water, that originates in the Alps goes through Antwerp and not Marseilles, Le Havre or even Dunkirk, because Antwerp offers better services for storage and lower cost for export. Moreover, the port of Antwerp is now digging a canal towards Paris, that recalls the failure of French projects such as Rhine-Rhone rivers' connection and "Seine-East" canal project, due to environmental and cultural concerns. Thus, despite its fantastic strategic position at the entrance of the English Channel which leads to the North Sea, the world's busiest sea lane, Le Havre's hinterland is considerably diminished due to the lack of efficient national plans for maritime and intermodal strategies. As a consequence, northern ports such as Antwerp, Rotterdam and Hamburg are in leading positions in all transport modes (rail, road, sea, river) and can pretend to cover the newly integrated EU members such as Poland and Hungary. As the gravity center of Europe is heading East, western ports such as Le Havre, which already suffer from severe institutional and technical constraints, might see their activity reducing in the near future, despite the planning of new port terminals.

In Asia, the absence of a single market doesn't prevent ports from competing with each other, mostly on "extra" freight such as transshipment ${ }^{1}$ flows. In the last 10 years, a number of ports have emerged so as to offer this type of service (hub) for an efficient distribution of freight to secondary ports. Singapore and Hong Kong, the world's busiest container ports, have been challenged in the throughput ranking by mostly hub ports such as Busan, Kaohsiung, Laem Chabang, Port Klang and Shanghai. In the case of Busan, South Korea, the hinterland function (Seoul region) has been progressively integrated with the hub function, notably after shipping lines moved there due to excessive handling costs in Japanese ports (Frémont and Ducruet, 2005). In fact, port competition is more dramatic for hub functions than for hinterlands. However, increasing integration of East Asian economies, that leads to increasing intra-regional waterborne trade, and the congestion level of the oldest nodes, that implies rising costs (e.g. handling charges), bring out new patterns of port development, like in the Pearl River Delta with the emergence of Shenzhen ports (Wang and Slack, 2000), and the complex network of port terminals arising from public and private operators' global strategies with a particular Asian trend (Slack and Wang, 2002). The risk for Asian ports is to rely heavily on the short-term transshipment opportunities offered by the concentration of shipping lines. The emergence of Tanjung Pelepas in Malaysia, rival of Singapore, of Shenzhen ports, more or less cooperating and competing with Hong Kong, and of Gwangyang, within the Korean "doublehub" strategy with Busan, is a sign that large cities are facing some limits to handle both national and interregional trade, because of their densely populated urban environment (Ness and Tanigawa, 1992). This accentuates the preference for non-marine related urban policies (Okuno, 2000).

\footnotetext{
${ }^{1}$ Transshipment refers to the handling of containers from one ship to another (e.g. mother vessel to feeder vessel) without using port terminals or inland generated products.
} 


\section{Population and traffic evolution in Europe and Asia}

By using simple indicators of centrality and intermediacy (Fleming and Hayuth, 1994) such as population and container throughput, some general trends on port-city relationships are highlighted.

\subsection{Port-city interdependence}

The correlation between metropolitan population and container throughput provides a good indicator of port-city interdependence (Table 1). The interdependence is clearly decreasing for both samples, what gives some evidence on the lesser importance of urban economies for new logistic systems, described in a vast number of works. In general, European port cities have a lower but stable port-city interdependence index, while Asian port cities had a strong interdependence but this has dramatically decreased. As observed by Kidwai in India (1989), this phenomenon is particularly keen in the Indian subcontinent, while values are more stable in Southeast Asia and more gradually declining in Northeast Asia. Inversely, port-city dependence has increased in Northwest Europe until 1995 and in Scandinavia after 1990, while it has been very irregular in southern Europe. This confirms the relative stability of the north European port system (Frémont and Soppé, 2005). In fact, southern Europe can be compared to the Indian subcontinent in terms of port concentration, hub strategies, and urban-port separation. This also confirms the high complexity of shipping networks in the Mediterranean and Caribbean basins (McCalla et al., 2004). This first step helps to understand the relation between port reorganization and port-city evolution.

Table 1

Correlation between urban population and container throughput by port region, 1980-2005

\begin{tabular}{lcccccccc}
\hline \multicolumn{1}{c}{ Region } & 2005 & 2000 & 1995 & 1990 & 1985 & 1980 & 1975 & 1970 \\
\hline \hline Northwest Europe & 0.408 & 0.574 & 0.594 & 0.594 & 0.563 & 0.540 & 0.519 & 0.378 \\
Scandinavia Baltic & 0.572 & 0.337 & 0.162 & 0.153 & 0.156 & 0.234 & - & - \\
West Med. Iberian Peninsular & 0.146 & 0.122 & 0.232 & 0.367 & 0.365 & 0.193 & 0.262 & 0.174 \\
East Med. Black Sea & 0.330 & 0.305 & 0.510 & 0.278 & 0.061 & 0.752 & 0.898 & 1.000 \\
\hline Northeast Asia & 0.292 & 0.349 & 0.407 & 0.457 & 0.584 & 0.625 & 0.614 & 0.636 \\
Southeast Asia & 0.308 & 0.304 & 0.286 & 0.336 & 0.416 & 0.312 & - & - \\
Indian Subcontinent & -0.149 & 0.020 & 0.303 & 0.461 & 0.437 & - & - & - \\
\hline Europe & 0.179 & 0.174 & 0.190 & 0.162 & 0.179 & 0.215 & 0.222 & 0.127 \\
Asia & 0.264 & 0.300 & 0.347 & 0.429 & 0.565 & 0.592 & 0.634 & 0.664 \\
\hline
\end{tabular}

Data sources: Moriconi-Ebrard, 1994; Brinkhoff, 2005; Helders, 2005; Lahmeyer, 2005; Containerisation International Yearbooks 


\subsection{City size and throughput concentration}

The evolution of container throughput distribution among different city sizes is another insight in the changing pattern of port-city relationships(Table 2). This phenomenon is, of course, influenced by the nature of urban settlements and the pace of urban growth in the two areas.

Table 2

Distribution of container traffics by urban size in Europe and Asia, 1970-2005 (Unit: \%, TEUs)

\begin{tabular}{|c|c|c|c|c|c|c|c|c|c|}
\hline Area & $\begin{array}{l}\text { Population } \\
\text { (thousands) }\end{array}$ & हैं & ¿্ণ & Һ̆ & হ & $\stackrel{\mathscr{\infty}}{2}$ & $\stackrel{\text { \& }}{\mathscr{\Omega}}$ & $\stackrel{n}{a}$ & $\stackrel{?}{9}$ \\
\hline \multirow{7}{*}{ Europe } & $0<200$ & 28.09 & 30.47 & 28.21 & 26.21 & 25.56 & 18.89 & 19.69 & 22.98 \\
\hline & $200<499$ & 10.52 & 10.08 & 11.39 & 14.89 & 15.90 & 17.43 & 18.27 & 18.78 \\
\hline & $500<999$ & 6.95 & 16.01 & 15.31 & 13.39 & 12.68 & 18.95 & 16.96 & 21.86 \\
\hline & $1,000<2,499$ & 33.96 & 27.14 & 29.97 & 39.89 & 40.94 & 39.55 & 43.75 & 36.37 \\
\hline & $2,500<4,999$ & 20.09 & 15.95 & 14.31 & 5.10 & 4.91 & 5.18 & 1.32 & 0.00 \\
\hline & $5,000<$ & 0.40 & 0.35 & 0.82 & 0.52 & 0.00 & 0.00 & 0.00 & 0.00 \\
\hline & Total & 100.00 & 100.00 & 100.00 & 100.00 & 100.00 & 100.00 & 100.00 & 100.00 \\
\hline \multirow{7}{*}{ Asia } & $0<200$ & 4.78 & 2.59 & 2.12 & 0.91 & 1.47 & 0.64 & 0.00 & 1.27 \\
\hline & $200<499$ & 1.22 & 1.15 & 1.55 & 1.01 & 0.96 & 1.16 & 1.23 & 4.46 \\
\hline & $500<999$ & 2.60 & 0.78 & 1.99 & 1.02 & 1.16 & 0.65 & 6.00 & 0.00 \\
\hline & $1,000<2,499$ & 17.86 & 6.37 & 2.72 & 5.06 & 17.57 & 14.71 & 20.10 & 2.22 \\
\hline & $2,500<4,999$ & 19.92 & 27.75 & 40.34 & 36.19 & 17.95 & 37.18 & 24.14 & 12.88 \\
\hline & $5,000<$ & 53.61 & 61.35 & 51.28 & 55.81 & 60.90 & 45.66 & 48.52 & 79.17 \\
\hline & Total & 100.00 & 100.00 & 100.00 & 100.00 & 100.00 & 100.00 & 100.00 & 100.00 \\
\hline
\end{tabular}

The most striking difference between Europe and Asia comes from the level of traffic distribution in small cities. In Europe, traffic is equilibrated between small (0 to 999,000) and large cities ( 1 to 2.5 million) along the period. The share of intermediate cities $(200,000$ to 999,000$)$ is gradually reducing from $40 \%$ to $17 \%$, while the proportion of larger cities ( 2.5 million and over) increases from $0 \%$ to $20 \%$. Such trends indicate that in Europe, traffic is kept in large cities, because of important economies of scale and regional radiance, but tends to shift from intermediate cities to smaller cities due to technical inadequacy and lesser centrality.

In Asia, most traffic is concentrated in the largest cities, and the share of cities under 1 million has only increased from 5\% to $8 \%$ from 1970 to 2005 . Thus, although port reorganization is seen more strikingly in Asia, traffics tend to follow the urban hierarchy. This shows the importance of already established centers such as Tokyo, Shanghai, Hong Kong, Manila, Singapore, Jakarta, and Mumbai, which are dominant economic centers of their national economy. This analysis partly verifies the hypothesis that the port activity in Asia is dependent on economic factors, of which the concentration of economic activities in major cities, while in Europe, the port activity is more 
influenced by geographical factors such as the distance to markets and hinterlands.

\subsection{Maritime dependence and urban density}

The distribution of the "maritime dependence index" proposed by Vigarié (1968) and developed by Kenyon (1974) for US cities is another means to testify the interplay of ports and port cities in Europe and Asia (Fig. 2). Unsurprisingly, the level of "transit function" (TEUs per inhabitant) highlights the importance of the main European gateways (i.e., the northern range from Le Havre to Hamburg and the West Mediterranean arc from Valencia to Genoa) and the Asian hubs (i.e., from Colombo to Busan).

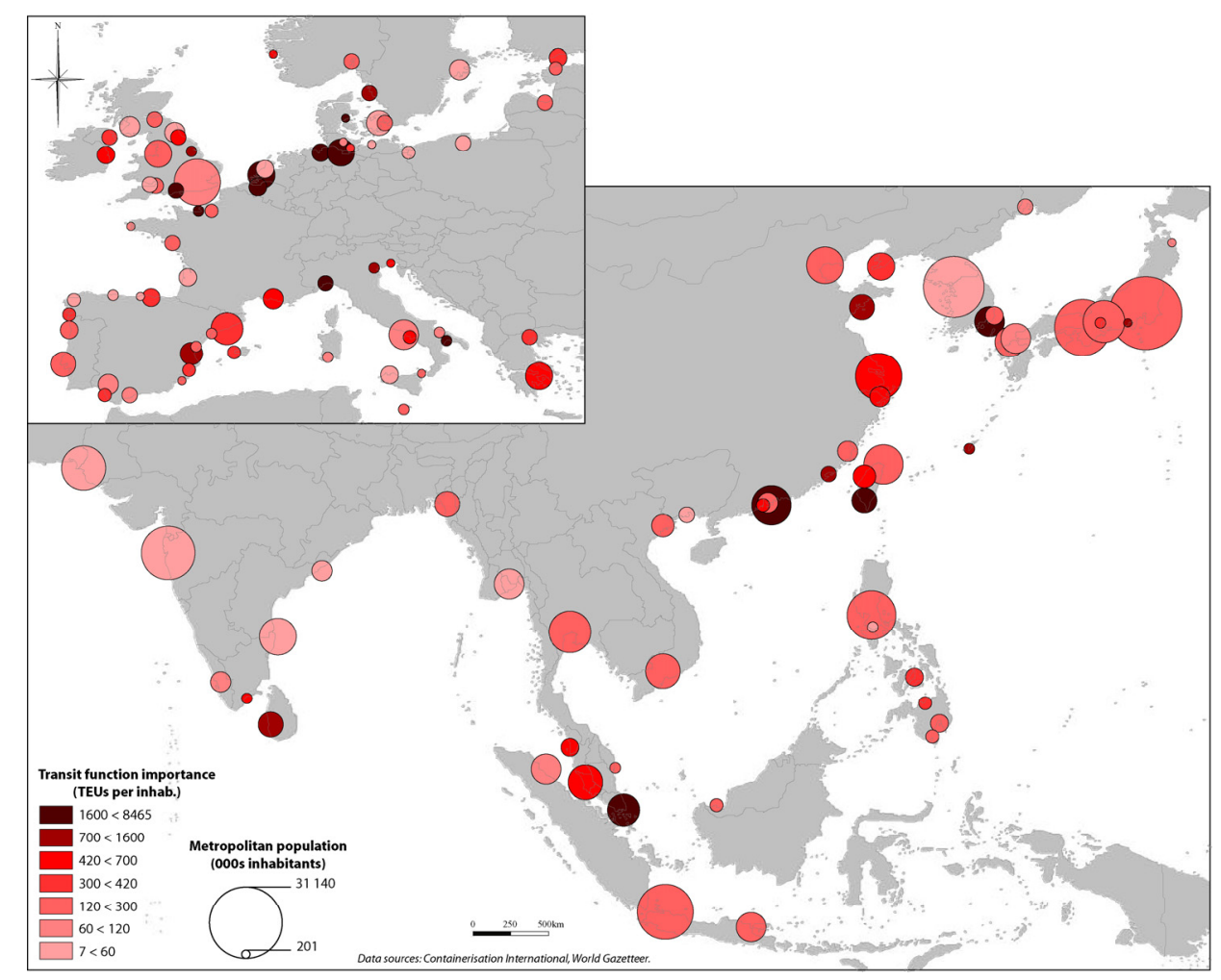

Fig. 2. City size and transit function of European and Asian port cities.

According to the density (Fig. 3), an interesting difference appears. In Europe, major container flows are not located in higher density nodes, showing the influence of a north-south pattern on port activities. Because Mediterranean port cities are historically more concentrated than northern port cities in terms of urban land use, the concentration of port activity is such cities has been 
limited. This also explains the urgent need for shipping lines to reorganize their networks through hub and spoke networks in the Mediterranean area, while in Northern Europe this could have been solved by the shift of port facilities to downstream deep-sea locations, as seen in the Anyport model of Bird (1963).

In Asia, the biggest cargo volumes are handled in high density nodes (e.g. Hong Kong, Kaohsiung). It highlights a specific trend of port concentration in developing countries (Hoyle, 2000b), which forces Asian ports to overcome the constraints of their urban environments by favouring higher productivity at the terminals. If in Europe, ports may "survive" from the disconnection with the local economy by expanding their hinterlands, this is not the case in Asia, where the coastal concentration of markets allows only a limited range of options in terms of port relocation. In Asia, ports are "forced" to follow the urban hierarchy, resulting in high congestion at the port-city interface, as seen in the Asian consolidation model of Lee (2005). Despite the trend of new port construction outside large port cities (e.g., Port Mohammad Bin Qasim from Karachi, Jawaharlal Nehru from Mumbai, Laem Chabang from Bangkok, Tanjung Pelepas from Singapore, Gwangyang and Busan New Port from Busan), inner ports in Asia keep a substantial amount of trade activity.

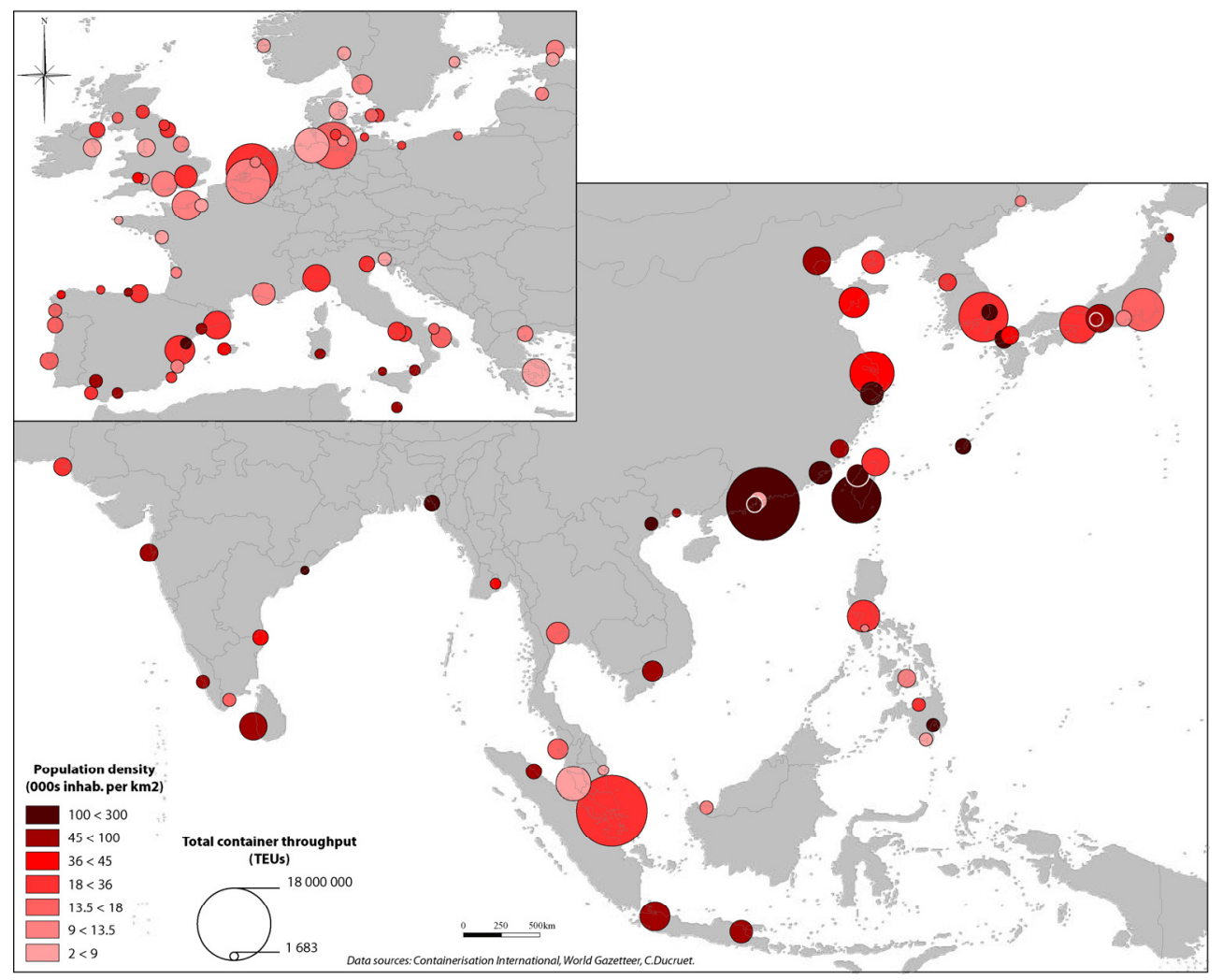

Fig. 3. Throughput size and urban density of European and Asian port cities 


\section{A typology of European and Asian port cities}

\subsection{Data and sample selection}

The sample of European and Asian port cities is based on two criteria: a minimum size of 200,000 inhabitants that is used for usual international urban comparison (Brunet, 1989; Rozenblat and Cicille, 2002) and a regular containerised trade activity, resulting in a total of 121 places. So as to enlarge the measure of port-city relationships, container traffic and urban population are complemented with other key indicators such as transport activities (container-related businesses and freight forwarders), port infrastructures and maritime networks (number of direct calls, total length and maximum depth of container terminals), and physical characteristics of the metropolitan area (urbanized area, number of highway and railway connections). In particular, some of them have been used for benchmarking European ports' infrastructures, but without looking at urban functions (Joly and Martell, 2003).

Table 4

Correlation difference between European and Asian data

\begin{tabular}{|c|c|c|c|c|c|c|c|c|c|}
\hline & 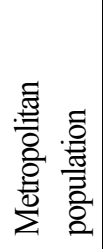 & 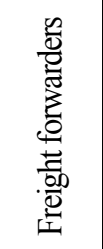 & 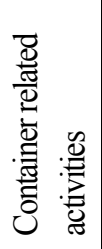 & 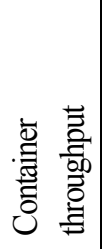 & 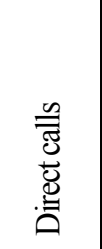 & 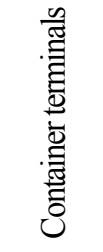 & 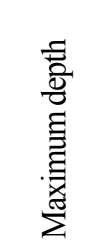 & 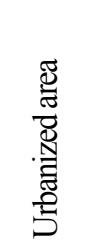 & 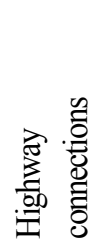 \\
\hline Freight forwarders & -0.012 & & & & & & & & \\
\hline Container related activities & -0.154 & -0.097 & & & & & & & \\
\hline Container throughput & -0.142 & -0.003 & -0.029 & & & & & & \\
\hline Direct calls & -0.136 & 0.117 & 0.004 & -0.046 & & & & & \\
\hline Container terminals & -0.318 & 0.128 & -0.045 & -0.063 & 0.005 & & & & \\
\hline Maximum depth & -0.136 & 0.228 & 0.064 & -0.148 & 0.007 & 0.051 & & & \\
\hline Urbanized area & -0.101 & 0.080 & -0.023 & 0.019 & -0.086 & -0.283 & -0.067 & & \\
\hline Highway connections & 0.294 & 0.428 & 0.274 & 0.161 & 0.053 & -0.090 & -0.242 & 0.342 & \\
\hline Railway connections & 0.112 & 0.143 & 0.002 & -0.031 & -0.162 & -0.156 & -0.099 & 0.177 & -0.142 \\
\hline
\end{tabular}

Notes $:$ bold $=$ Asian preference $(<-0.1)$; italic $=$ European preference $(>0.1)$; other $=$ similar correlation

1. Population of the metropolitan area: the number of inhabitants in the whole urbanised area expresses the scale of the immediate market served by the port;

2. Surface of the metropolitan area: the size of the perimeter covered by continuous urbanisation shows in which type of settlement does the port functions develop. This has been calculated 
manually (Ducruet, 2004) from online geographical atlas;

3. Number of highways connecting the port city: the total highway connections serving the port city gives an idea of the potential for port hinterland coverage from the terminals through road transport (trucks);

4. Number of railways connecting the port city: the total railway connections serving the port city is a good indicator of insertion within land systems and might reflect a potential of intermodality between sea and land for containers, although this does not prove the real connection between port and rail tracks for the handling of goods;

5. Length of container terminals: the total amount of container terminal frontage is an indicator of modernity, as containers developed since the 1970s, for the handling of manufactured goods;

6. Maximum depth of the container terminals: given the increase in vessel size, the maximum depth for container terminals gives the nautical accessibility level of port infrastructures in a competitive context;

7. Container throughput: the total amount of TEUs (Twenty-Foot Equivalent Units) reflects the level of a port's activity and insertion within the transport chain. The difficulty comes from distinguishing real trade coming from the port's hinterland (sea-land) and redistribution from one ship to another (sea-sea), as this information is strategic and usually lacks;

8. Total number of containerised direct calls: the total amount of regular services calling at port (mother vessels) from shipping lines (service offered by ship-owners) is an indicator of foreland wideness and stability for the port activity;

9. Number of container-related services: the total amount of such activities (ship-owners, repair, distribution, inspection, clearance, warehousing) give an idea of the level of transport functions around a port;

10. Number of international forwarding agents: the total amount of forwarding and logistics agents (e.g. DHL, Panalpina, Kuehne \& Nagel, ABX, Damco) show the degree of attractiveness of a place for its insertion within sea and land networks.

The interaction between those indicators is different in the two areas (Table 5). From the two separated correlation matrixes, the difference is calculated between Asia and Europe. Values higher than 0.1 and lower than -0.1 are interpreted as European or Asian specificities. In Asia, urban population has a higher correlation than Europe with other indicators. In Europe, transport connections, which are used as a surrogate for the importance of hinterlands, have a higher correlation than Asia with other indicators. Another European specificity is the higher correlation between freight forwarders and port infrastructures and maritime connections. Although this again confirms the role of cities in Asia and of hinterlands in Europe, an analysis of the distribution of those trends throughout the two areas is needed. 
Table 5

Presentation of the factors

\begin{tabular}{|c|c|c|c|c|}
\hline & $\begin{array}{c}\text { F1 } \\
(54.70 \%)\end{array}$ & $\begin{array}{c}\mathbf{F 2} \\
(15.03 \%)\end{array}$ & $\begin{array}{c}\mathbf{F 3} \\
(9.51 \%)\end{array}$ & $\begin{array}{c}\mathbf{F 4} \\
(5.47 \%)\end{array}$ \\
\hline & Container hierarchy & Inland connections & $\begin{array}{c}\text { Sea-land } \\
\text { accessibility }\end{array}$ & $\begin{array}{c}\text { Logistic } \\
\text { specialisation }\end{array}$ \\
\hline \multirow{8}{*}{$>0$} & Direct calls & Railways & Maximal depth & \multirow{8}{*}{$\begin{array}{r}\text { Forwarders } \\
\mathbf{( 3 8 . 7 2 \% )} \\
\text { Container companies } \\
(20.39 \%) \\
\text { Railways } \\
(1.04 \%) \\
\text { Highways } \\
(0.06 \%)\end{array}$} \\
\hline & Container throughnut & Highways & Terminals' length & \\
\hline & $(13.59 \%)$ & $(38.80 \%)$ & $(9.29 \%)$ & \\
\hline & Container companies & \multirow{5}{*}{$\begin{array}{r}\text { Urban area } \\
(2.65 \%)\end{array}$} & Railways & \\
\hline & $(13.20 \%)$ & & $(3.33 \%)$ & \\
\hline & Terminals' length & & Highways & \\
\hline & $(12.42 \%)$ & & $(2.15 \%)$ & \\
\hline & $\begin{array}{r}\text { Freight forwarders } \\
(11.31 \%)\end{array}$ & & $\begin{array}{r}\text { Direct calls } \\
(1.44 \%)\end{array}$ & \\
\hline \multirow{11}{*}{$<0$} & \multirow{10}{*}{-} & Container companies & & Maximal depth \\
\hline & & $(0.62 \%)$ & & $(0.45 \%)$ \\
\hline & & Terminals' length & Container companies & Direct calls \\
\hline & & $(0.97 \%)$ & $(3.93 \%)$ & $(1.44 \%)$ \\
\hline & & Maximal depth & Forwarders & Terminals' length \\
\hline & & $(2.78 \%)$ & $(5.00 \%)$ & $(9.29 \%)$ \\
\hline & & Direct calls & Urban area & Urban area \\
\hline & & $(5.45 \%)$ & $(15.69 \%)$ & $(11.59 \%)$ \\
\hline & & Container throughput & Population & Population \\
\hline & & $(5.57 \%)$ & $(16.94 \%)$ & $(22.12 \%)$ \\
\hline & & Shipping connections & $\begin{array}{c}\text { City size and logistic } \\
\text { activities }\end{array}$ & $\begin{array}{l}\text { Port-city } \\
\text { combination }\end{array}$ \\
\hline
\end{tabular}

\subsection{Interpretation of principal components}

The analysis is operated for the entire database of 121 cities, allowing how the common trends of port-city relationships are diversely distributed among the two areas. The four main principal components concentrate almost $85 \%$ of the original information, each one showing a specific trend (Table 5):

- a hierarchy of the port activity (direct calls, port throughput, container-related businesses, and container terminals): "logistic hierarchy (F1)"

- an opposition between transport connections (railways, highways) and port activity (throughput, calls, depth, terminals, companies): "hinterland / foreland (F2)"

- an opposition between urban functions (city size and logistic activities) and port infrastructures 
(depth and length of terminals): "urban magnitude / accessibility (F3)"

- an opposition between transport functions (logistic activities and transport connections) and urban functions (city size): "logistic specialization / port-city combination(F4)"

\subsection{Geographical distribution of port-city relationships}

The first distribution (Figure 4) confirms the importance of the European "ring", located around the heartland (Le Havre-Hamburg and Valencia-Genoa), and followed by a few peripheral metropolises such as Lisbon, Leixoes (Porto), Bilbao, Naples and Piraeus (Athens) in the south; Dublin, Liverpool, Gothenburg and Helsinki in the north. In Asia, the major port cities also appear, from Tokyo-Yokohama to Karachi. We can notice that any Asian port city which is not on the major sea route is a minor node, like in the Philippines, with the concentration in Manila disfavouring other ports.

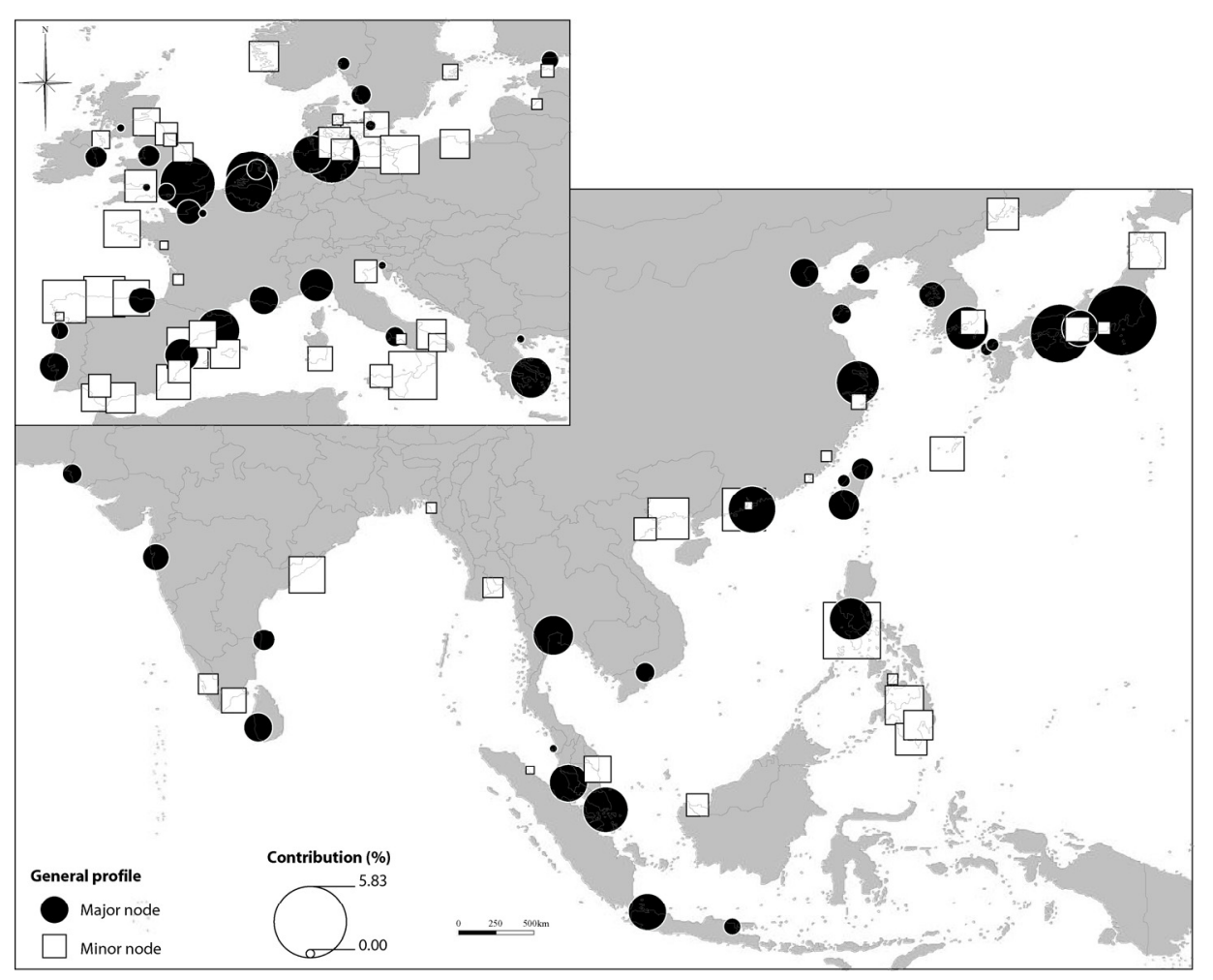

Fig. 4. Distribution of F1 scores

The second distribution (Fig. 5) is much more contrasted than the previous one. There is a radical opposition between south and north Europe, and between Japan and the rest of Asia, apart 
from a few exceptions. Northern European port cities are fundamentally central places at the crossroads of land transport modes and at the head of large hinterlands (estuaries), while southern European port cities have limited inland radiance, due to physical (Alps, Pyrenees) and historical factors. Only Le Havre, Aarhus and Bergen show a "maritime" profile, as they have in common that their shipping activity surpasses the size of the local economy and the degree of hinterland penetration. Although some southern cities have a lower maritime activity (e.g., Sevilla, Santander, Bilbao, Naples, and Bari), the case of Barcelona is better explained by its strategic situation close to the French border, that strengthens its inland radiance. Thus, Barcelona has been defined as a "northern city located in the south" (Garcia, 1992), as its port function has "a lower importance than for other port cities" (Sagarra Y Trias, 1992). In Asia, few port cities have developed their hinterland connections.

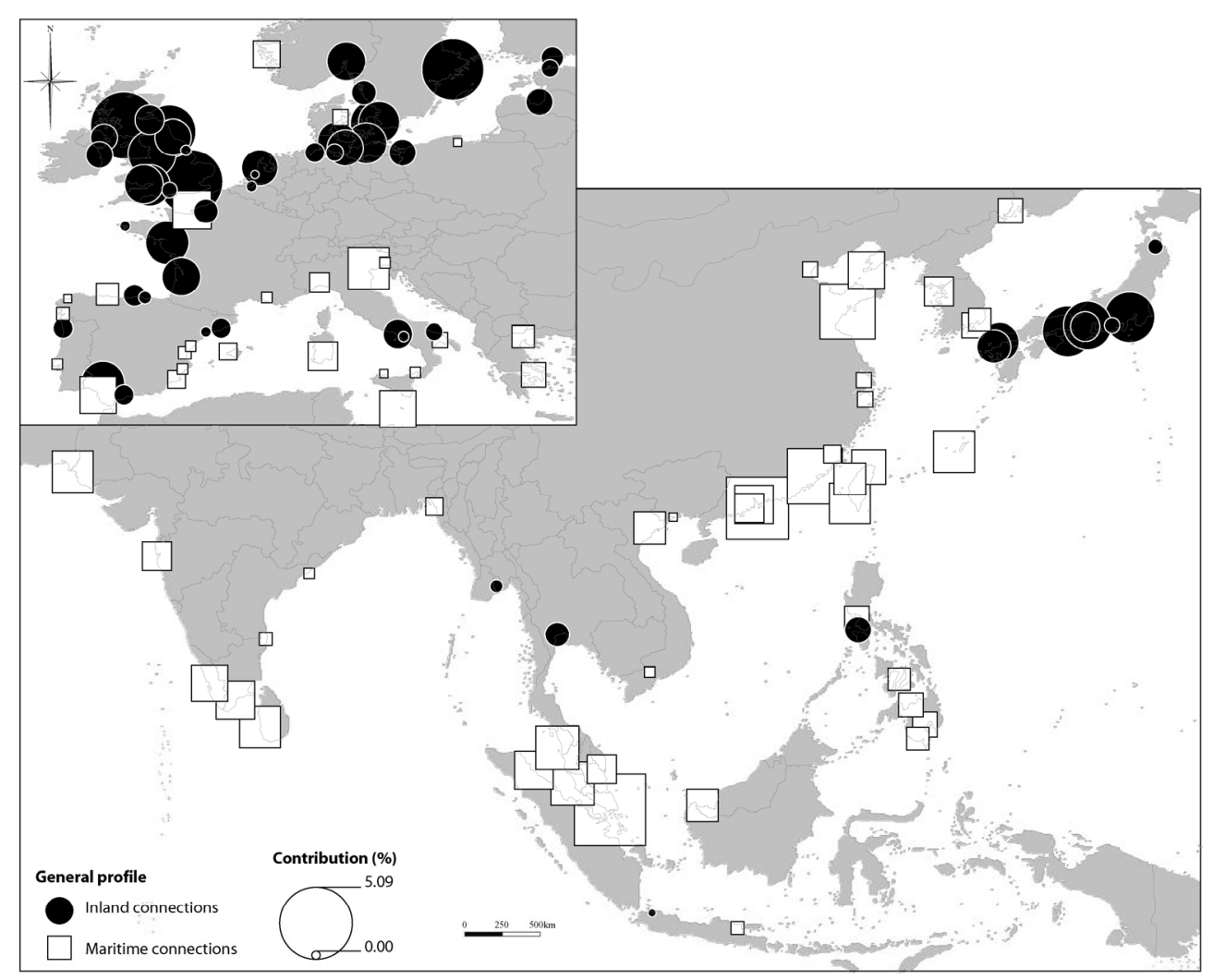

Fig. 5. Distribution ofF2 scores

The third distribution (Fig. 6) shows a clear sub-regional differentiation in both areas. The trend of sea-land accessibility is concentrated in Northeast Asia, while in Europe it is mostly distributed around the heartland. Inversely, the trend of city size is confined in South and Southeast Asia, while 
in Europe it is mainly in the north with the British Isles and the Scandinavia / Baltic region. This reflects the fact that the accessibility of ports has improved around the major markets. The city size is in fact more important where port modernization has been less efficient, and where urban policies have accompanied the shift of port functions from physical handling to broader services (e.g., Singapore, Mumbai, London, Stockholm and Oslo).

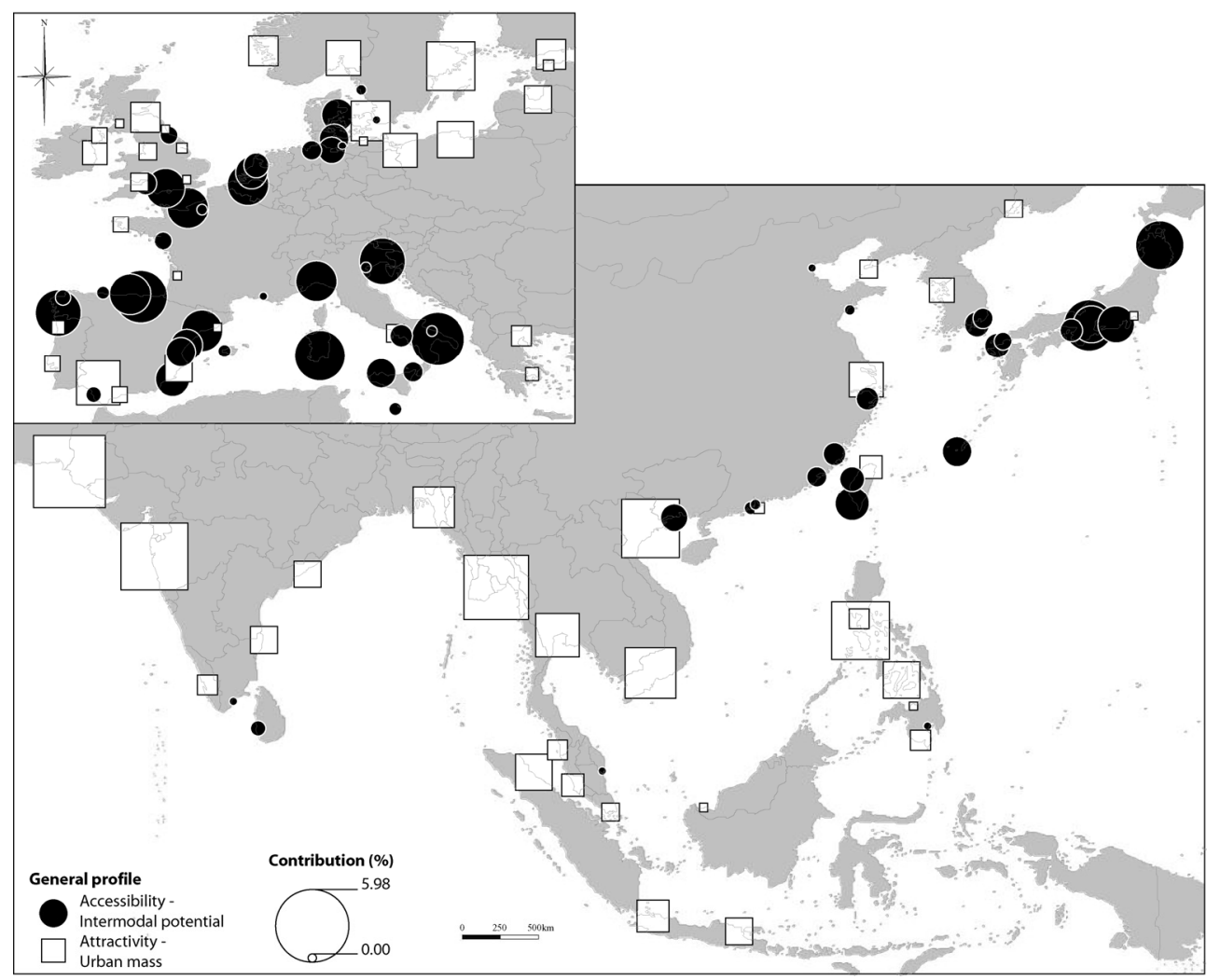

Fig. 6. Distribution of F3 scores

The fourth distribution (Fig. 7) appears, this time, to oppose a majority of European and Asian nodes. In spite of its lower statistical significance, F4 has a meaningful geographical logic. European port cities are much more specialised in the logistic function (i.e. distribution, storage, transfer) because they are the gateways between core regions and the outside world (cf. Fig. 1). For this reason, it is quite rare to find a logic reason of port-city combinations in Europe, where portrelated functions have, comparatively with other areas of the world, a stronger importance for the local economy. It has been argued elsewhere (Ducruet, 2005) that this specificity of European port cities has led to a number of contradicting opinions about the role of ports in enhancing local economic development, as it is a hard task in Europe but a natural process in many other areas. 
This also verifies the "lock-in effect" of urban systems (Fujita and Mori, 1996), based on the idea that port cities in centralised urban systems are "blocked" and remain specialised when they are dependent and well connected to core regions. It also shows that in Asia, the distribution of goods needs less logistic agents due to closer markets and a simpler transport chain. Thus, Asian port cities have a better port-urban combination than in Europe, where the transport chain is more complex and forces ports to compete inland through intermodal services and hinterland expansion.

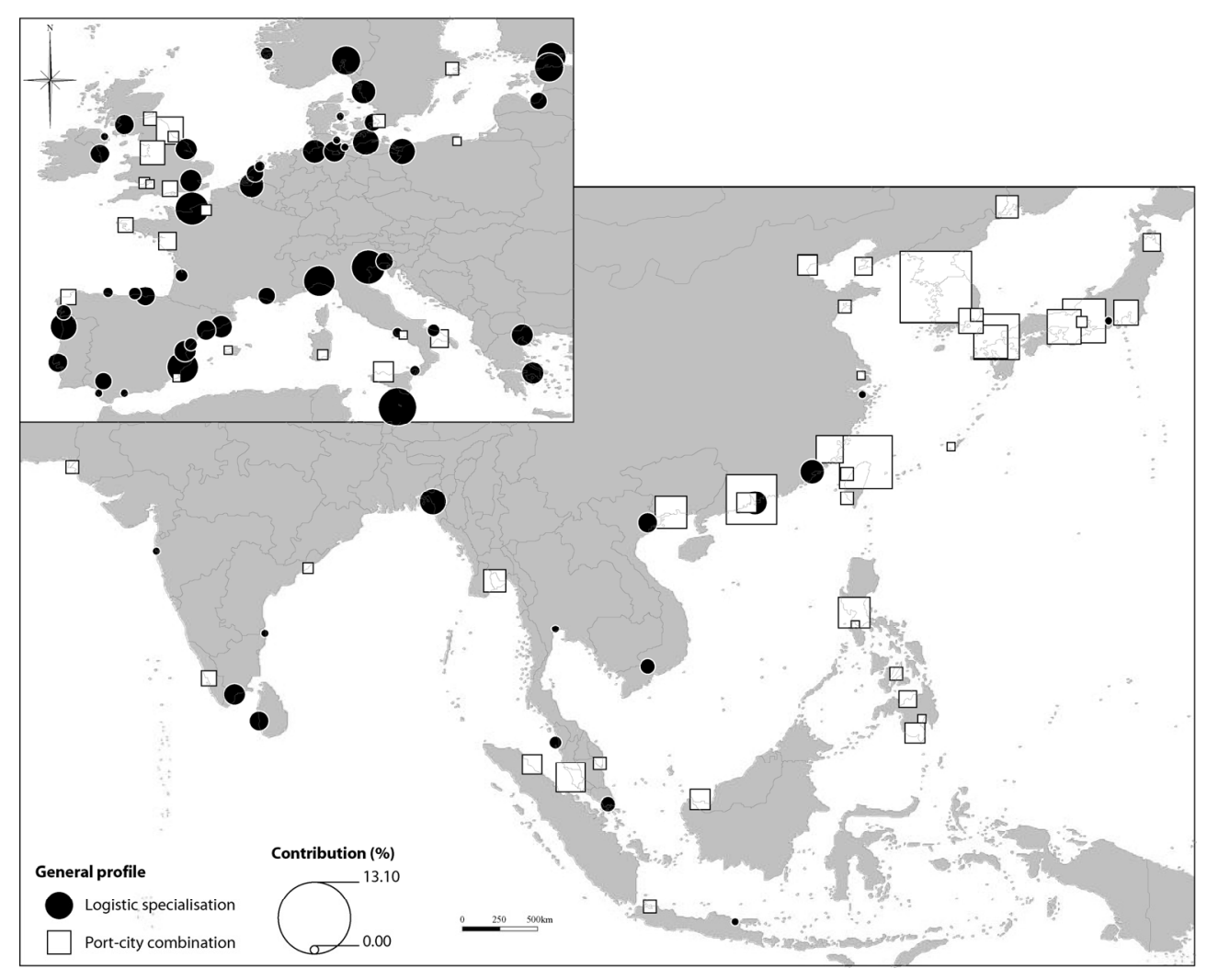

Fig. 7. Distribution ofF4 scores

\subsection{Are European and Asian port cities comparable?}

So as to synthesize the results of the factor analysis, we propose a typology of the cities studied (Fig. 8). This allows us to verify which port cities are comparable and why. As F4 factor strongly opposed the two areas, we keep only F1, F2 and F3 to build the typology. According to those factors, four different types can be distinguished:

- General port cities: a reduced importance of port functions in the local economy, favouring central place functions but lowering port competitiveness. Major urban centres dominate this 
category, with financial poles (Tokyo, London), national and regional capitals (Bangkok, Helsinki, Copenhagen, Oslo, Dublin, Barcelona, Glasgow, Naples and Leixoes). It also shows the remotely located port cities of the Atlantic Arc and the Scandinavia Baltic areas;

- Hub port cities: port functions dominate the local economy, through efficient port concentration but limited hinterland penetration. The only European major nodes to be compared to Asian ones are located in southern Europe: Lisbon, Piraeus (Athens), Thessaloniki. Asian port cities dominate this category due to the limitation of their hinterlands;

- Hinterland port cities: port functions are important for a local economy specialized in industrial and logistic activities which serve large hinterlands. This is seen in Europe with port cities facing the lockin effect of core regions (e.g., Le Havre, Marseilles with Paris; Genoa, Trieste with Milan, Turin; Valencia with Madrid). This is similar to the Asian cases of Busan, Kaohsiung, Taichung and Tianjin, which are also dependent on their close centralized markets (Seoul, Taipei, and Beijing);

- Maritime port cities: port functions are limited compared to other urban functions but port activity is kept despite the pressure from the urban environment. Those port cities are found mostly in Japan, where the risk of congestion has been overcome by gigantic reclamation projects, and in northern Europe thanks to the downstream shift of port functions along estuaries (Maas delta for Antwerp and Rotterdam, Severn river for Bristol, Solent river for Southampton, Seine river for Rouen, Weser river for Bremen and Elbe river for Hamburg). Without such geographical advantage and territorial strategies, these port cities would have become without any doubt "general cities", gradually losing their port function due to congestion.

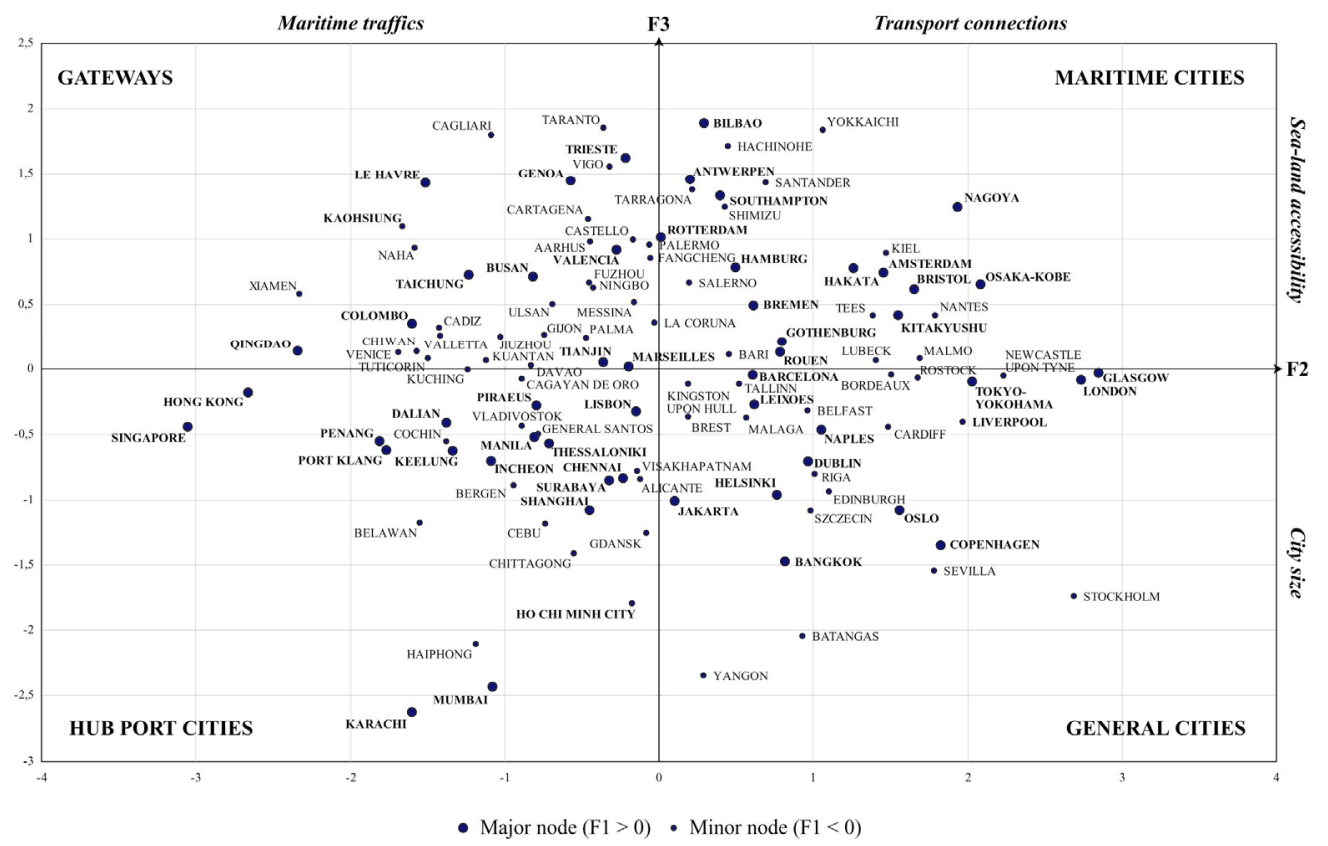

Fig. 8. Typology of European and Asian port cities 


\section{Conclusion}

This research has proposed an international comparison of port-city relationships in Europe and Asia. It has showed the decreasing interdependence of port and urban systems in the two areas, although major cities keep a major share of container traffics. The analysis of port-city relationships, although it uses very basic indicators of urban and port functions, helps reveal the importance of macro factors. In Europe, the distance to inland markets and the extension of hinterlands is a main factor to explain the relative importance of urban and port functions, while in Asia, there is more a combined port-city hierarchy due to the lack of hinterlands. While such trends are suggested in the literature, this paper could, at least, verify them by putting separately studied areas on a common ground. Of course, more effort should be given to the improvement of statistical measures, notably of urban economic activities, so as to better consider the respective role of industrial and tertiary activities when dealing with ports. Despite such limitations, the study indicates the fundamental differences between European and Asian port cities. It provides a base upon which further research shall be done for the comparison of case studies. The main message is that port cities shall be compared based on objective profiles rather than only port throughputs that are the usual - and sometimes the only - reference to justify a comparison. Although any typology is not an end in itself, it clearly shows that the main ports in Europe and Asia are not directly comparable. The volume of throughputs is generated in very contrasting environments, but those environments are often ignored by port specialists. Further comparison of port cities should consider the urban dimension and degree of hinterland expansion of ports before putting "global ports" in the same category.

\section{Appendix A}

Database on European port cities

\begin{tabular}{|c|c|c|c|c|c|c|c|c|c|c|}
\hline PORT CITY & $\begin{array}{l}\text { 茎 } \\
\text { 国 }\end{array}$ & $\begin{array}{l}\text { 崩 } \\
\text { 音 }\end{array}$ & 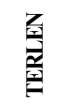 & 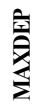 & 矛 & 屬 & $\sum_{0}^{\mathbb{U}}$ & 齐 & 象 & $\frac{n}{\delta}$ \\
\hline AARHUS & 500,000 & 15 & 1,500 & 14 & 226 & 79 & 1 & 4 & 1 & 48 \\
\hline ALICANTE & 146,477 & 4 & 354 & 10 & 428 & 36 & 0 & 3 & 12 & 14 \\
\hline AMSTERDAM & 44,511 & 28 & 5,360 & 14 & 1,188 & 107 & 5 & 7 & 13 & 26 \\
\hline ANTWERPEN & $6,063,746$ & 374 & 16,190 & 16 & 933 & 96 & 8 & 5 & 26 & 189 \\
\hline BARCELONA & $1,882,878$ & 136 & 4,370 & 14 & 4,973 & 141 & 5 & 7 & 79 & 81 \\
\hline BARI & 35,000 & 6 & 990 & 10 & 303 & 20 & 1 & 5 & 3 & 5 \\
\hline BELFAST & 229,000 & 11 & 747 & 9 & 585 & 30 & 3 & 4 & 1 & 26 \\
\hline BERGEN & 110,359 & 8 & 310 & 10 & 213 & 59 & 1 & 1 & 1 & 33 \\
\hline BILBAO & 468,960 & 43 & 2,118 & 21 & 1,120 & 52 & 3 & 7 & 15 & 43 \\
\hline BORDEAUX & 46,385 & 10 & 690 & 12 & 971 & 88 & 3 & 7 & 9 & 9 \\
\hline
\end{tabular}




\begin{tabular}{|c|c|c|c|c|c|c|c|c|c|c|}
\hline BREMEN & $3,469,104$ & 54 & 4,040 & 15 & 1,001 & 221 & 5 & 6 & 26 & 105 \\
\hline BREST & 19,917 & 1 & 400 & 11 & 213 & 87 & 2 & 1 & 1 & 6 \\
\hline BRISTOL & 100,493 & 10 & 1,050 & 14 & 616 & 156 & 5 & 6 & 5 & 10 \\
\hline CADIZ & 150,909 & 11 & 580 & 12 & 407 & 11 & 0 & 1 & 1 & 22 \\
\hline CAGLIARI & 28,432 & 60 & 1,520 & 14 & 292 & 5 & 0 & 2 & 0 & 8 \\
\hline CARDIFF & 41,461 & 3 & 250 & 9 & 720 & 17 & 3 & 4 & 1 & 6 \\
\hline CARTAGENA & 27,523 & 3 & 1,280 & 13 & 201 & 10 & 0 & 2 & 0 & 6 \\
\hline CASTELLO & 35,041 & 8 & 167 & 12 & 290 & 3 & 0 & 3 & 1 & 3 \\
\hline CATANIA & 0 & 7 & 290 & 12 & 852 & 14 & 2 & 3 & 0 & 3 \\
\hline COPENHAGEN & 135,000 & 10 & 375 & 10 & 2,366 & 150 & 5 & 6 & 5 & 77 \\
\hline DUBLIN & 540,779 & 37 & 1,087 & 11 & 1,024 & 247 & 5 & 4 & 14 & 53 \\
\hline EDINBURGH & 169,300 & 6 & 320 & 8 & 696 & 32 & 3 & 3 & 1 & 7 \\
\hline GDANSK & 24,074 & 6 & 275 & 10 & 867 & 60 & 1 & 2 & 3 & 9 \\
\hline GENOA & $1,628,594$ & 143 & 9,993 & 15 & 692 & 24 & 3 & 4 & 20 & 126 \\
\hline GIJON & 3,172 & 5 & 326 & 12 & 285 & 10 & 1 & 0 & 1 & 10 \\
\hline GLASGOW & 34,200 & 5 & 376 & 13 & 1,379 & 86 & 9 & 10 & 7 & 23 \\
\hline GOTENBURGH & 731,000 & 26 & 1,603 & 12 & 786 & 65 & 3 & 7 & 6 & 90 \\
\hline HAMBURG & $7,003,479$ & 318 & 9,553 & 17 & 3,278 & 231 & 9 & 6 & 42 & 296 \\
\hline HELSINKI & 500,000 & 31 & 415 & 11 & 1,215 & 108 & 8 & 2 & 15 & 76 \\
\hline KIEL & 27,454 & 4 & 1,070 & 10 & 235 & 9 & 4 & 4 & 0 & 5 \\
\hline KINGSTONUPON HULL & 292,345 & 17 & 300 & 10 & 302 & 26 & 2 & 3 & 2 & 27 \\
\hline LACORUNA & 8,000 & 3 & 400 & 11 & 387 & 10 & 1 & 2 & 0 & 2 \\
\hline LEHAVRE & $2,150,000$ & 242 & 6,075 & 15 & 254 & 24 & 2 & 2 & 19 & 67 \\
\hline LEIXOES & 331,741 & 51 & 900 & 12 & 1,218 & 77 & 4 & 4 & 27 & 27 \\
\hline LISBON & 514,679 & 72 & 1,883 & 14 & 2,613 & 170 & 3 & 3 & 30 & 75 \\
\hline LIVERPOOL & 578,000 & 21 & 707 & 13 & 3,562 & 473 & 5 & 10 & 2 & 38 \\
\hline LONDON & $1,132,700$ & 138 & 2,100 & 16 & 11,327 & 408 & 15 & 24 & 60 & 213 \\
\hline LUBECK & 78,778 & 10 & 647 & 10 & 213 & 63 & 3 & 5 & 1 & 12 \\
\hline MALAGA & 70,000 & 8 & 236 & 9 & 843 & 10 & 2 & 3 & 1 & 10 \\
\hline MALMO & 135,000 & 2 & 1,050 & 9 & 598 & 21 & 5 & 4 & 1 & 8 \\
\hline MARSEILLES & 916,000 & 60 & 2,750 & 14 & 1,573 & 174 & 3 & 3 & 20 & 68 \\
\hline MESSINA & 61,449 & 0 & 165 & 11 & 237 & 4 & 1 & 2 & 0 & 2 \\
\hline NANTES & 119,385 & 2 & 1,593 & 13 & 765 & 226 & 5 & 5 & 8 & 3 \\
\hline NAPLES & 430,000 & 49 & 374 & 14 & 3,770 & 155 & 3 & 8 & 10 & 35 \\
\hline NEWCASTLE UPON TYNE & 44,937 & 3 & 514 & 11 & 1,428 & 54 & 5 & 6 & 0 & 4 \\
\hline OSLO & 177,019 & 11 & 563 & 10 & 808 & 175 & 5 & 5 & 9 & 92 \\
\hline PALERMO & 20,000 & 11 & 700 & 15 & 987 & 20 & 2 & 2 & 1 & 11 \\
\hline PALMA & 183,300 & 1 & 1,070 & 11 & 475 & 11 & 0 & 2 & 0 & 15 \\
\hline
\end{tabular}




\begin{tabular}{|c|c|c|c|c|c|c|c|c|c|c|}
\hline PIRAEUS & $1,605,135$ & 64 & 3,100 & 17 & 3,231 & 370 & 2 & 3 & 50 & 209 \\
\hline RIGA & 150,000 & 10 & 450 & 10 & 843 & 84 & 2 & 6 & 4 & 37 \\
\hline ROSTOCK & 1,683 & 2 & 143 & 9 & 205 & 8 & 2 & 5 & 0 & 11 \\
\hline ROTTERDAM & $8,281,000$ & 462 & 10,250 & 17 & 3,328 & 118 & 7 & 5 & 30 & 211 \\
\hline ROUEN & 126,468 & 25 & 2,040 & 12 & 535 & 171 & 3 & 4 & 4 & 16 \\
\hline SALERNO & 329,760 & 47 & 1,654 & 11 & 533 & 21 & 3 & 3 & 3 & 9 \\
\hline SANTANDER & 10,007 & 1 & 839 & 13 & 229 & 5 & 2 & 3 & 1 & 6 \\
\hline SEVILLA & 102,854 & 4 & 760 & 7 & 1,312 & 17 & 5 & 4 & 6 & 10 \\
\hline SOUTHAMPTON & $1,441,012$ & 83 & 1,350 & 15 & 764 & 61 & 3 & 6 & 1 & 42 \\
\hline STOCKHOLM & 33,550 & 3 & 240 & 9 & 1,692 & 441 & 6 & 6 & 2 & 27 \\
\hline SZCZECIN & 14,008 & 1 & 125 & 9 & 505 & 15 & 1 & 5 & 2 & 18 \\
\hline TALLINN & 111,599 & 7 & 400 & 13 & 394 & 67 & 2 & 4 & 6 & 47 \\
\hline TARANTO & 763,318 & 15 & 1,500 & 14 & 255 & 17 & 1 & 5 & 1 & 5 \\
\hline TARRAGONA & 53,086 & 3 & 489 & 14 & 357 & 5 & 2 & 3 & 2 & 11 \\
\hline TEES & 318,587 & 13 & 660 & 11 & 675 & 31 & 4 & 6 & 0 & 17 \\
\hline THESSALONIKI & 336,096 & 31 & 600 & 12 & 829 & 68 & 3 & 1 & 18 & 25 \\
\hline TRIESTE & 131,200 & 21 & 1,420 & 18 & 201 & 86 & 2 & 3 & 6 & 22 \\
\hline VALENCIA & $2,145,236$ & 120 & 4,039 & 16 & 1,740 & 67 & 2 & 7 & 28 & 63 \\
\hline VALLETTA & 51,666 & 7 & 352 & 12 & 258 & 4 & 0 & 0 & 5 & 30 \\
\hline VENICE & 283,667 & 21 & 510 & 12 & 259 & 9 & 0 & 1 & 8 & 19 \\
\hline VIGO & 161,952 & 30 & 1,021 & 17 & 419 & 27 & 2 & 3 & 4 & 18 \\
\hline
\end{tabular}

\section{Appendix B}

Database on Asian port cities

\begin{tabular}{|c|c|c|c|c|c|c|c|c|c|c|}
\hline PORT CITY & 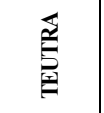 & 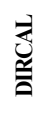 & $\begin{array}{l}\text { 罙 } \\
\text { 童 } \\
\text { 型 }\end{array}$ & 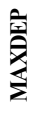 & 氡 & 武 & 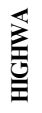 & 离 & 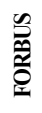 & $\frac{n}{8}$ \\
\hline BANGKOK & $1,073,517$ & 85 & 3,417 & 11 & 8,838 & 595 & 6 & 4 & 37 & 107 \\
\hline BATANGAS & 2,566 & 1 & 342 & 5 & 247 & 20 & 0 & 2 & 0 & 2 \\
\hline BELAWAN(MEDAN) & 273,704 & 46 & 850 & 11 & 3,800 & 70 & 0 & 1 & 4 & 24 \\
\hline BUSAN & $7,540,387$ & 547 & 11,040 & 15 & 4,298 & 156 & 5 & 2 & 9 & 52 \\
\hline CAGAYAN DE ORO & 148,482 & 2 & 300 & 11 & 461 & 16 & 0 & 0 & 0 & 3 \\
\hline CEBU & 404,116 & 21 & 1,141 & 9 & 1,223 & 98 & 0 & 2 & 4 & 21 \\
\hline CHENNAI & 321,960 & 40 & 600 & 15 & 6,677 & 177 & 2 & 3 & 18 & 55 \\
\hline CHIBA & 57,535 & 7 & 240 & 12 & 31,139 & 879 & 6 & 5 & 0 & 302 \\
\hline CHITTAGONG & 324,147 & 19 & 450 & 9 & 2,592 & 16 & 0 & 3 & 14 & 33 \\
\hline CHIWAN(SHENZHEN) & 400,000 & 75 & 1,270 & 15 & 1,500 & 0 & 0 & 0 & 0 & 6 \\
\hline
\end{tabular}




\begin{tabular}{|c|c|c|c|c|c|c|c|c|c|c|}
\hline COCHIN & 133,178 & 20 & 680 & 11 & 1,408 & 20 & 0 & 0 & 1 & 32 \\
\hline COLOMBO & $1,732,855$ & 193 & 2,546 & 15 & 2,436 & 38 & 0 & 3 & 21 & 71 \\
\hline DALIAN & $1,011,000$ & 91 & 1,173 & 14 & 3,221 & 157 & 0 & 2 & 7 & 31 \\
\hline DAVAO & 145,372 & 17 & 250 & 11 & 1,195 & 4 & 2 & 0 & 1 & 12 \\
\hline FANGCHENG & 5,000 & 2 & 500 & 14 & 744 & 11 & 2 & 0 & 0 & 1 \\
\hline FUZHOU & 400,200 & 18 & 1,050 & 14 & 1,546 & 32 & 2 & 2 & 1 & 15 \\
\hline GENERAL SANTOS & 115,363 & 2 & 588 & 11 & 411 & 63 & 0 & 0 & 0 & 7 \\
\hline HACHINOHE & 25,673 & 7 & 530 & 13 & 241 & 5 & 3 & 2 & 0 & 1 \\
\hline HAIPHONG & 219,000 & 16 & 342 & 8 & 1,820 & 16 & 0 & 1 & 7 & 22 \\
\hline HAKATA(FUKUOKA) & 510,721 & 85 & 840 & 13 & 4,200 & 29 & 5 & 7 & 1 & 9 \\
\hline HOCHI MINH CITY & 733,236 & 80 & 486 & 10 & 5,894 & 108 & 2 & 3 & 24 & 44 \\
\hline HONG KONG & $18,100,000$ & 716 & 6,791 & 15 & 8,190 & 44 & 0 & 2 & 83 & 274 \\
\hline INCHEON(SEOUL) & 611,261 & 43 & 9,585 & 14 & 21,738 & 28 & 2 & 1 & 2 & 14 \\
\hline JUZHOU (ZHUHAI) & 235,000 & 3 & 700 & 9 & 371 & 4 & 0 & 0 & 0 & 0 \\
\hline KAOHSIUNG & $7,425,832$ & 297 & 6,047 & 15 & 2,557 & 21 & 2 & 2 & 6 & 56 \\
\hline KARACHI & 615,024 & 69 & 600 & 11 & 10,537 & 428 & 1 & 1 & 23 & 61 \\
\hline KAWASAKI & 43,707 & 14 & 431 & 14 & 31,139 & 1,895 & 5 & 6 & 0 & 302 \\
\hline KEELUNG(TAIPEI) & $1,954,573$ & 178 & 3,192 & 12 & 8,030 & 2 & 1 & 2 & 0 & 24 \\
\hline KITAKYUSHU & 412,043 & 38 & 1,895 & 12 & 4,193 & 98 & 5 & 7 & 0 & 6 \\
\hline KOBE & $2,265,992$ & 285 & 11,205 & 15 & 17,621 & 531 & 3 & 5 & 0 & 113 \\
\hline KUANTAN & 62,783 & 12 & 620 & 12 & 289 & 38 & 0 & 0 & 1 & 12 \\
\hline KUCHING & 110,474 & 14 & 1,248 & 11 & 423 & 41 & 0 & 0 & 1 & 13 \\
\hline MANILA & $2,867,836$ & 167 & 8,278 & 15 & 13,790 & 584 & 2 & 3 & 12 & 82 \\
\hline MUMBAI & 429,448 & 31 & 1,388 & 11 & 16,368 & 240 & 2 & 1 & 31 & 145 \\
\hline NAGOYA & $1,911,920$ & 312 & 3,555 & 15 & 8,610 & 115 & 10 & 14 & 1 & 31 \\
\hline NAHA & 303,337 & 17 & 540 & 11 & 302 & 2 & 1 & 0 & 0 & 4 \\
\hline NINGBO & 902,000 & 2 & 900 & 14 & 1,399 & 11 & 2 & 2 & 3 & 16 \\
\hline OSAKA & $1,474,201$ & 234 & 3,765 & 14 & 17,621 & 531 & 13 & 18 & 6 & 113 \\
\hline PENANG & 635,780 & 46 & 931 & 12 & 1,033 & 59 & 0 & 0 & 8 & 31 \\
\hline PORT KLANG & $3,206,753$ & 367 & 4,379 & 15 & 6,139 & 44 & 0 & 2 & 14 & 57 \\
\hline QINGDAO & 2,120000 & 162 & 1,000 & 16 & 2,536 & 67 & 0 & 1 & 7 & 34 \\
\hline SHANGHAI & $5,613,000$ & 322 & 2,281 & 13 & 12,039 & 286 & 2 & 5 & 27 & 111 \\
\hline SHIMIZU & 361,700 & 40 & 1,160 & 12 & 236 & 19 & 4 & 3 & 0 & 18 \\
\hline SINGAPORE & $17,040,000$ & 612 & 5,919 & 15 & 4,591 & 153 & 1 & 1 & 42 & 278 \\
\hline TAICHUNG & $1,130,357$ & 55 & 2,437 & 14 & 2,131 & 18 & 0 & 3 & 4 & 22 \\
\hline TANJUNG PERAK & 949,029 & 54 & 1,450 & 11 & 3,788 & 49 & 2 & 3 & 11 & 34 \\
\hline TANJUNG PRIOK & $2,222,496$ & 24 & 2,338 & 14 & 17,891 & 283 & 3 & 4 & 24 & 103 \\
\hline
\end{tabular}




\begin{tabular}{|c|c|c|c|c|c|c|c|c|c|c|}
\hline TIANIN & $1,708,423$ & 54 & 2,450 & 15 & 6,809 & 135 & 2 & 4 & 10 & 35 \\
\hline TOKYO & $2,899,452$ & 234 & 4,321 & 15 & 31,139 & 1,895 & 12 & 20 & 18 & 302 \\
\hline TUTICORIN & 136,612 & 30 & 283 & 12 & 252 & 16 & 0 & 1 & 2 & 28 \\
\hline ULSAN & 236,296 & 53 & 240 & 12 & 1,155 & 5 & 1 & 3 & 1 & 8 \\
\hline VISAKHAPATNAM & 20,427 & 4 & 168 & 10 & 1,381 & 12 & 0 & 2 & 1 & 11 \\
\hline VLADIVOSTOK & 70,000 & 5 & 303 & 12 & 646 & 49 & 1 & 1 & 0 & 7 \\
\hline XIAMEN & $1,084,700$ & 112 & 972 & 13 & 738 & 6 & 0 & 1 & 8 & 30 \\
\hline YANGON & 49,453 & 9 & 500 & 8 & 4,344 & 109 & 0 & 3 & 2 & 19 \\
\hline YOKKAICHI & 103,500 & 30 & 550 & 13 & 291 & 6 & 4 & 5 & 0 & 3 \\
\hline YOKOHAMA & $2,317,489$ & 344 & 6,030 & 16 & 31,139 & 1,895 & 6 & 6 & 2 & 302 \\
\hline
\end{tabular}

\section{References}

Arasaratnam, Sinnappah. 1992. Pre-colonial and early-colonial port towns. In Ports and their hinterlands in India 1700-1950, ed. I. Banga, 367-372. New Delhi: Manohar.

Basu, Dilip K. ed. 1985. The Rise and growth of the colonial port cities in Asia. Berkeley: Center for South and South East Asian Studies.

Benacchio, Marco, Claudio Ferrari, Hercules E. Haralambides, and Enrico Musso. 2001. "On the economic impact of ports: Local vs. national costs and benefits." Paper presented at the $9^{\text {th }}$ World Conference on Transport Research, Seoul, Korea.

Bird, James. 1963. The major seaports of the United Kingdom. London: Hutchinson of London.

Bird, J. 1973. Of central places, cities and seaports. Geography 58: 105-118.

Brinkhoff, Thomas. Cities and agglomerations of the world.

http://www.citypopulation.de/cities.html, accessed by November 2006.

Broeze, Frank, ed. 1989. Brides of the sea: Port cities of Asia from the $16^{\text {th }}-20^{\text {th }}$ centuries. Honolulu: University of Hawaii Press.

Broeze, Frank, ed. 1997. Gateways of Asia: Port cities of Asia in the $13^{\text {th }}-20^{\text {th }}$ centuries. London \& New York: Kegan Paul International.

Brunet, Roger. 1989. Les Villes « Européennes ». Montpellier : DATAR \& GIP RECLUS.

Containerisation International Online. CI-online directory and port database. Containerisation International Web site. http://www.ci-online.co.uk, accessed by November 2006.

Ducruet, C. 2003. Comparing european and East Asian port cities: Are global databases relevant sources for research? Bulletin of the Institute of Business and Economic Research(Inha Univ.) 17, no.2: 139-159.

Ducruet, C. 2004. The Trans-scalar development of transportation hubs: A quantitative comparison of European and East Asian container port cities in the 1990s." Bulletin of the Institute of Business and Economic Research(Inha Univ.) 18, no.2: 171-199. 
Ducruet, C. 2005. Approche Comparée du Développement des Villes-ports à l'Echelle Mondiale: Problèmes Théoriques et Méthodologiques. Cahiers Scientifiques du Transport 48: 59-79.

Ducruet, César, and Ok-Ju Jeong. 2005. European port-city interface and its asian application. Anyang: Korea Research Institute for Human Settlements.

Ducruet, César, Olivier Joly, and Hipolito Martell. 2005. Air-sea Linkages in European port cities: Development impact on transport and logistic activities. Paper presented at the $5^{\text {th }}$ Inha-Le Havre International Conference, Le Havre, France.

Fleming, D.K., and Hayuth, Y. 1994. Spatial characteristics of transportation hubs: Centrality and intermediacy. Journal of Transport Geography 2, no.1: 3-18.

Frémont, A., and Ducruet, C. 2005. The emergence of a mega port, from the local to the global, the Case of Busan. Tijdschrift voor Econ. En Soc. Geografie 96, no.4: 421-432.

Frémont, A., and Soppé, M. 2005. The servicing of the European northern range by shipping lines (1994 - 2002): A process of concentration or dispersion? Flux 59: 22-32.

Fujita, M., and Mori, T. 1996. The role of ports in the making of major cities: Self-agglomeration and hub-effect. Journal of Development Economics 49, no.1: 93-120.

Garcia, S. 1992. La Modernisation de Barcelone. Cahiers de la Recherche Architecturale 30/31: 13-22.

Gipouloux, François. 2001. Complementary and rivalry among Asia's major logistics hubs: Hong Kong, Singapore and Shanghai in a global perspective. Paper presented at the $4^{\text {th }}$ Europe-Asia Conference, Hong Kong, China, November 2001.

Helders, Stefan. World gazetteer. http://www.world-gazetteer.com/home.htm, accessed by November 2006.

Hoyle, B.S. 2000a. Global and local change on the port-city waterfront. The Geographical Review 90, no.3: 395-417.

Hoyle, Brian S. 2000b. Global and Local Forces in Developing Countries. Journal for Maritime Research,http://www.jmr.nmm.ac.uk/upload/amaxus_pdf/amaxus_conJmrArticle_20. pdf, accessed by November 2006.

Hoyle, Brian S., and David Pinder, ed. 1992. European port cities in transition. London: Belhaven Press, 1992.

International Transport Journal. International register of logistics and forwarding agents. International Transport Journal Web site. http://195.65.73.10/itz/irflaNeu/e/irfla_suche.asp, accessed by November 2006.

I.R.S.I.T. 2004. Les villes Portuaires en Europe, Analyse Comparative. Montpellier: CNRS \& Institut de Recherches en Stratégies Industrielles et Territoriales.

Joly, Olivier, and Hipolito Martell. 2003. Infrastructure benchmarks for european container ports. Paper presented at the $4^{\text {th }}$ Inha-Le Havre International Conference, Incheon, Korea, October 2003.

Kenyon, James B. 1974 Elements in inter-port competition in the United States. In Transportation geography: Comments and reading, ed. M.E. Eliot Hurst, 231-253. New York: McGraw Hill Series in Geography, 1974.

Kidwai, Atiya H. 1989. Port cities in a national system of ports and cities: A geographical Analysis 
of India in the $20^{\text {th }}$ Century. In Brides of the sea: Port cities of Asia from the $16^{\text {th }}-20^{\text {th }}$ centuries, ed. F. Broeze, 207-222. Honolulu: University of Hawaii Press.

Lahmeyer, Jan. Population statistics. http://www.library.uu.nl/wesp/populstat/populhome.html, accessed by November 2006.

Lawton, Richard, and Robert Lee, ed. 2002. Population and society in Western European port cities, c. 1650-1939. Liverpool: Liverpool University Press.

Lee, Sung Woo. 2005. Interaction between city and port in Asian hub port cities, Ph.D. diss., Seoul National University.

Lee, S.W., D.W. Song and C. Ducruet, C. A tale of Asia's world ports: The spatial evolution in global hub port cities. Geoforum (forthcoming).

Mc Calla, Robert, Brian Slack, and Claude Comtois. 2004. The geographical hierarchy of container shipping networks in the caribbean basin and mediterranean sea. Paper presented at the $10^{\text {th }}$ World Conference on Transport Research, Istanbul, Turkey, July 2004.

Moriconi-Ebrard, François. 1994. Geopolis: Pour Comparer les Villes du Monde. Paris: Economica.

Ness, Gayl D., and Kanae Tanigawa, ed. 1992. Population dynamics and port city development: Comparative analysis of ten Asian port cities. Kobe: Asian Urban Information Center.

Okuno, Shii. 2000. Urban policies of some port cities in the Asia-Pacific corridor. In Urban growth and development in Asia, ed. G.P. Chapman, A.K. Dutt, and R.W. Bradnock, 426-439. Aldershot: Ashgate.

Rodrigue, Jean-Paul, Comtois, C., and Slack, B. The geography of transport systems. http://www.geog.umontreal.ca/Geotrans/fr/ ch3fr/conc3fr/ch3c3fr.html, accessed by November 2006.

Rozenblat, Céline., and Patricia Cicille. 2002. Les Villes Européennes : Analyse Comparative. Montpellier: DATAR \& Maison de la Géographie.

Sagarra, Y Trias, F. 1992. Barcelone, la dynamique olympique et le projet urbain. Cahiers de la Recherche Architecturale 30/31: 23-34.

Slack, B., and Wang, J.J. 2002. The challenge of peripheral ports: An Asian perspective. GeoJournal 56, no.3. 2002.: 159-166.

Vigarié, André. 1968. Géographie de la Circulation, 2: La Circulation Maritime. Paris: Genin.

Wang, J.J., and Olivier, D. 2003. La Gouvernance des Ports et la Relation Ville-port en Chine. Les Cahiers Scientifiques du Transport 44: 25-54.

Wang, J.J., and Slack, B. 2000. The evolution of a regional container port system: The Pearl River Delta. Journal of Transport Geography 8, no.4: 263-275. 
